\title{
The Effect of Basil Leaves (Ocimum Basilicum) Addition to Contents of $\beta$-Carotene, Calcium Levels, and Hedonic Test of Basil Leaves Biscuits
}

\author{
Y W Ningsih ${ }^{1}$, M Devi $^{2}$, T M Kiranawati ${ }^{3}$ \\ ${ }^{1}$ Department of Industrial Technology, Faculty of Engieering, Universitas Negeri Malang, Indonesia \\ ${ }^{2,3}$ Advisors, Department of Industrial Technology, Faculty of Engieering, Universitas Negeri Malang, Indonesia
}

\begin{abstract}
Biscuits are one of the products with many peoples liked. With advances in technology, biscuits can be added with vegetables to improve their nutritional content. The biscuits was increase with basil leaves puree are expected to help meet the deficiency of $\beta$-carotene, calcium levels in breastfeeding mothers and smoothen breast milk. This research aims to know $\beta$-carotene content, calcium levels, and hedonic test (preference test) in breastfeeding mothers on basil leaves biscuits by adding $10 \%, 15 \%$, and $20 \%$ basil leaves puree. The experiment is using complete random design (CDR) with three replication. Data result of the research were analyzed statistically using ANOVA and Duncan's Multiple Range Test (DMRT). The result of the research showed that there are different on $\beta$-carotene content all of increased basil leaves puree. The highest $\beta$ carotene content was obtained by basil leaves biscuits with the formulation of adding basil leaves puree as much as $20 \%$ with a value of $878,355 \mu \mathrm{g} / 100 \mathrm{~g}$. The more of basil leaves puree is added so the $\beta$-carotene contentof biscuits also increased. The highest calcium content was obtained by basil leaves biscuits with the formulation of adding basil leaves puree as much as $20 \%$ with a value of $250,893 \mathrm{mg} / 100 \mathrm{~g}$. The more basil leaves puree added to calcium levels the more it increased. The result showed there was different favorites levels of breastfeeding mother on the taste, texture, colour, and flavour. The most preferred level of taste for basil leaves biscuits is in the formulation of adding $10 \%$ basil leaves puree with a value of 4.71 . The most preferred level of preference for the texture of basil leaves biscuits is in the formulation of adding $10 \%$ basil leaves puree with a value of 4.54 . The most preferred level of preference for the color of basil leaves biscuits is in the formulation of adding $15 \%$ basil leaves puree with a value of 4.46 . The most preferred level of aroma of basil leaves biscuits is in the formulation of adding $15 \%$ basil leaves puree with a value of 4.37 .
\end{abstract}

Keywords: ocimum basilicum, bet carote, calcium, hedonic, biscuit

\section{INTRODUCTION}

Biscuits are one of the products that are popular with the community. With the advancement in technology, biscuits can be turned into delicious, nutritious, good-looking food that is beneficial to health (Astawan, 2008). Many biscuit products on the market with certain brands began to be added with vegetables to add nutritional value.

Vegetables that can be added are basil leaves. Utilization of basil leaves into food products is still limited. Basil leaves are usually only consumed as fresh vegetables and seasonings added to food. Basil (Ocinum Basilicum) can be used as galactogagum (galactogague). Galactagogum or can also be called laktagogum. The use of lactagogum (lactagogue) is one way that can be done to increase the rate of secretion and milk production (Syarief, dkk. 2014). Basil contains $\beta$-carotene which is quite high and good for nursing mothers. The function of $\beta$-carotene for the human body is as a source of vitamin $\mathrm{A}$, therefore $\beta$-carotene is known as provitamin A (Aini, 2010: 43). Vitamin A is an important micronutrient because it helps activate cells to collect milk in the breast (Chahyanto dan Roosita, 2013: 84). According to Halwati's research, (2015) Vitamin A also affects the production of breast milk.

Basil leaves, including vegetables that contain lots of calcium and phosphorus minerals, as many as 45 and 75 $\mathrm{mg}$ per $100 \mathrm{~g}$ of basil leaves (Lee, 2004). Calcium is the main mineral in breast milk. Nursing women are prone to calcium deficiency (Kundre, dan Pondag. 2017). If a nursing mother lacks calcium, it will have an impact on the health of her baby because calcium plays a role in the formation of bones and teeth in the baby.

Efforts that can prevent calcium deficiency are by consuming additional food. Therefore consuming biscuits added with basil leaves is expected to help meet the deficiency of $\beta$-carotene, calcium and can expedite breast milk in nursing mothers. This study will examine the 
content of $\beta$-carotene, calcium content of basil leaves biscuits with the addition of basil leaves puree and examine the hedonic properties (preferences) of breastfeeding mothers on basil leaves biscuits.

\section{RESEARCH METHOD}

The research conducted was an experimental study. The study design uses a completely random design (CRD) with one factor, namely basil leaves and four levels, namely $0 \%, 10 \%, 15 \%$ and $20 \%$. The treatment in this study was the addition of different types of basil leaves to the basil leaves biscuits by adding $10 \%, 15 \%$ and $20 \%$ basil leaves puree. Repetition is carried out 2 times so that the total experimental unit is 8 .

The main ingredient in making basil leaves puree is basil leaves that are still fresh, all parts of the basil leaves can be used either young or old. Basil is the type of lime basil. The ingredients for making basil biscuits include cake flour, margarain, icing sugar, skim milk, egg yolks, salt, and baking soda. The tools used in the process of making basil biscuits are scales, blenders, rolling pins, bowls, basins, spoons, pans, biscuit molds, measuring cups, mixers, ovens, and jars.

The hedonic (preferences) test is included in the acceptance test group. A hedonic test was conducted to determine the response of breastfeeding mothers about the level of liking and dislike of basil leaves biscuit products with different formulations for adding basil leaves puree. The hedonic test carried out included taste, texture, color, and flavour of basil leaves biscuits with the formulation of adding basil leaves puree as much as $10 \%, 15 \%$, and $20 \%$. The panelists involved were breastfeeding mothers from Posyandu Kelurahan Sumbersari, Lowokwaru, Malang City.

Data obtained from the test results of $\beta$-carotene content, calcium content, and hedonic properties test include data on the level of taste, texture, color and aroma of biscuits, then analyzed using the One Way ANOVA method with a significance level of $5 \%$. If there are significant differences (significant), then proceed by using the Duncan's Multiple Range Test (DMRT) to determine the degree of difference in each treatment.

\section{THE RESULTS AND DISCUSSION $\beta$-carotene content}

$\beta$-carotene content of basil leaves biscuits with the formulation of adding basil leaves puree as much as $10 \%, 15 \%$, and $20 \%$ can be seen in Picture 4.1

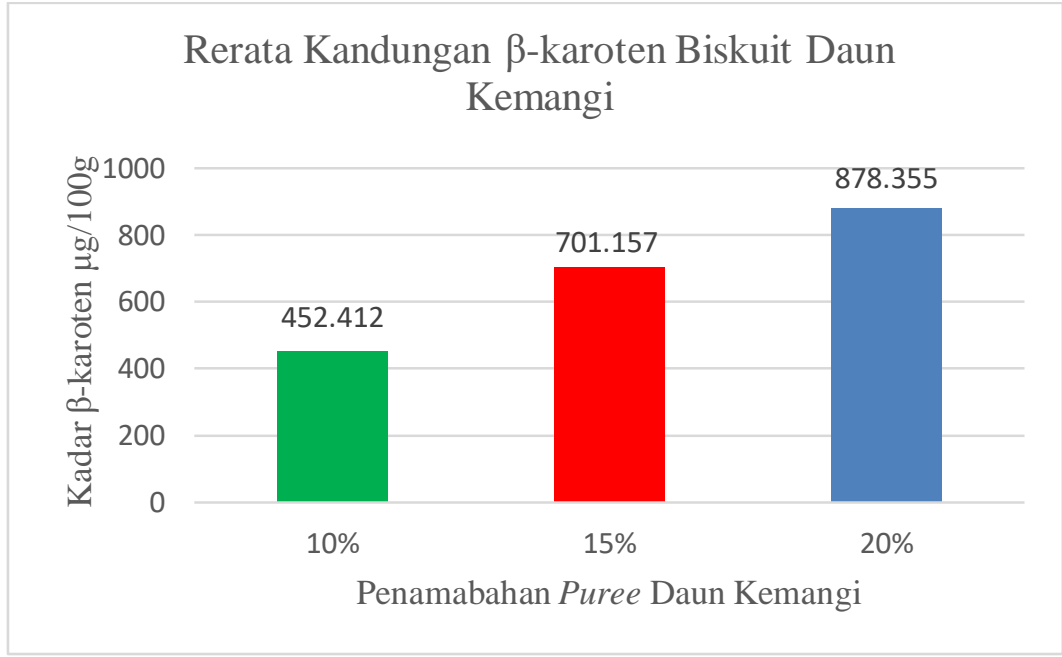

Picture 4.1: Average $\beta$-carotene Contents of Basil Leaves Biscuits

ANOVA analysis results showed that there were significant differences in the $\beta$-carotene content of basil leaves biscuits with the addition of basil leaves puree as much as $10 \%, 15 \%$, and $20 \%$. This is indicated by the significance value of $0,000<0.05$. Then continued with the Duncan's multiple range test (DMRT) to be used to determine the differences in each treatment.

It is known, based on Duncan's Multiple Range Test (DMRT) test results that there are significant differences in each treatment. Basil biscuits with the formulation of adding basil leaves puree as much as $10 \%, 15 \%$, and $20 \%$ each different. The mean value of $\beta$-carotene content of basil leaves biscuits has a tendency of different values, this is thought to occur because the treatment of adding basil leaves puree with different concentrations in making biscuits can increase $\beta$-carotene content.

The increase in $\beta$-carotene content can be seen from the average content of $\beta$-carotene of basil leaves biscuits which increases with each formulation of basil leaves puree as much as $452,41250 \mu \mathrm{g} / 100 \mathrm{~g}$ addition of $10 \%$ basil leaves puree, $701,157 \mu \mathrm{g} / 100 \mathrm{~g}$ with the addition of basil leaves puree as much as 452,41250 $\mu \mathrm{g} / 100 \mathrm{~g}$ addition of $10 \%$ basil leaves puree, 701,157 $\mu \mathrm{g} / 100 \mathrm{~g}$ with the addition of basil leaves puree as much as $15 \%$, and 
basil per 100 grams of 750 RE (Retinol Equivalents). Biscuit processing can damage and decrease $\beta$-carotene content. $\beta$-carotene is easily oxidized when exposed to air, decreased levels of $\beta$-carotene can also occur if the heating process is longer (Erawati, 2006). In this research, there is a heating process that is baking biscuits.
$878,355 \mu \mathrm{g} / 100 \mathrm{~g}$ with the addition of basil leaves puree as much as $20 \%$.

Basil biscuits with a formulation of adding $20 \%$ basil leaves puree has a higher $\beta$-carotene content compared to the addition of basil leaves puree by $10 \%$, and $15 \%$. According to Made (2015) the content of provitamin A

\section{Calcium Levels}

Calcium Levels of basil leaves biscuits with the formulation of adding basil leaves puree as much as $10 \%$, $15 \%$, and $20 \%$ can be seen in the Picture 4.2.

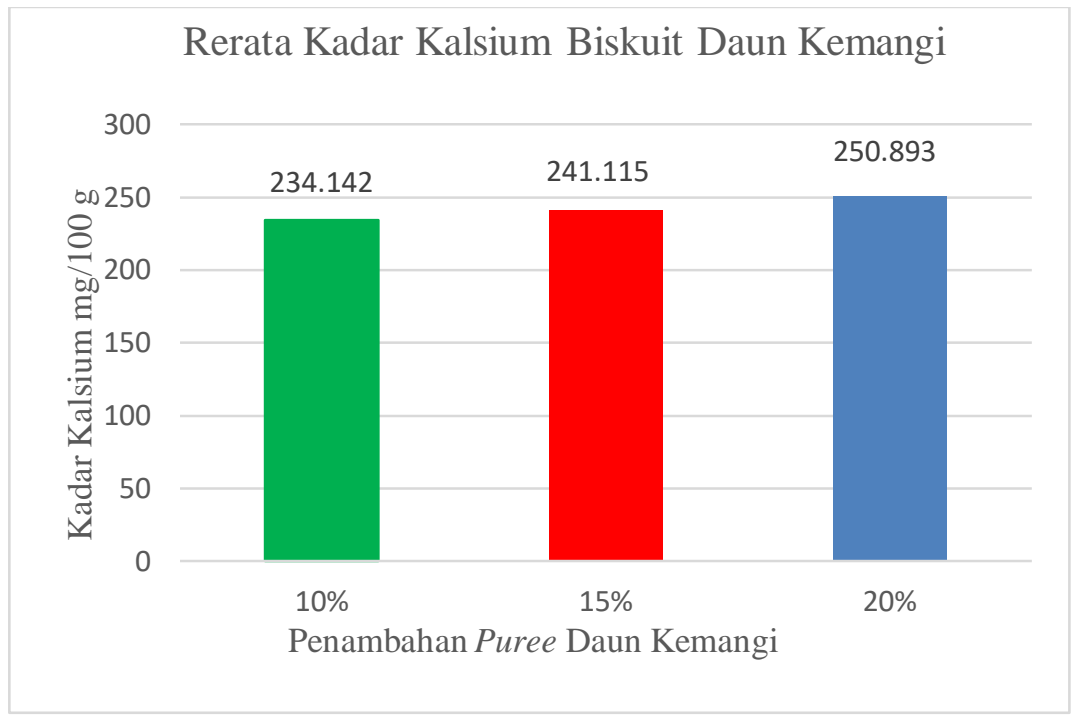

Picture 4.2: Average Calcium Levels of Basil Leaves Biscuits

ANOVA analysis results showed that there were significant differences in the calcium levels of basil leaves biscuits with the addition of basil leaves puree as much as $10 \%, 15 \%$, and $20 \%$. This is indicated by the significance value of $0,000<0.05$. Then continued with the Duncan's multiple range test (DMRT) to be used to determine the differences in each treatment.

It is known, based on Duncan's Multiple Range Test (DMRT) test results that there are significant differences in each treatment. Basil leaves biscuits with the formulation of adding basil leaves puree as much as $10 \%$, $15 \%$, and $20 \%$ each different. The mean value of calcium levels of basil leaves biscuits has a tendency of different values, this is thought to occur because the treatment of adding basil leaves puree with different concentrations in making biscuits can increase calcium levels.

Increased calcium levels can be seen from the average calcium levels of basil leaves biscuits which increase each formulation of basil leaves puree addition which is $234,142 \mathrm{mg} / 100 \mathrm{~g}$ with formulations of adding basil leaves puree as much as $10 \%, 241,115 \mathrm{mg} / 100 \mathrm{~g}$ with formulations adding as much as $15 \%$ basil leaves, and $250,893 \mathrm{mg} / 100 \mathrm{~g}$ with $20 \%$ basil leaves puree addition formulation.

Increased calcium is due to the addition of basil leaves puree. The content of calcium in basil leaves in 100 grams is $154.00 \mathrm{mg}$ (Riana, 2000). Calcium levels in food ingredients are not affected by the processing (Muchtadi, 2010). 


\section{Taste Hedonic}

Taste hedonic of basil leaves biscuits with the formulation of adding basil leaves puree as much as $10 \%, 15 \%$, and $20 \%$ can be seen in the Picture 4.3.

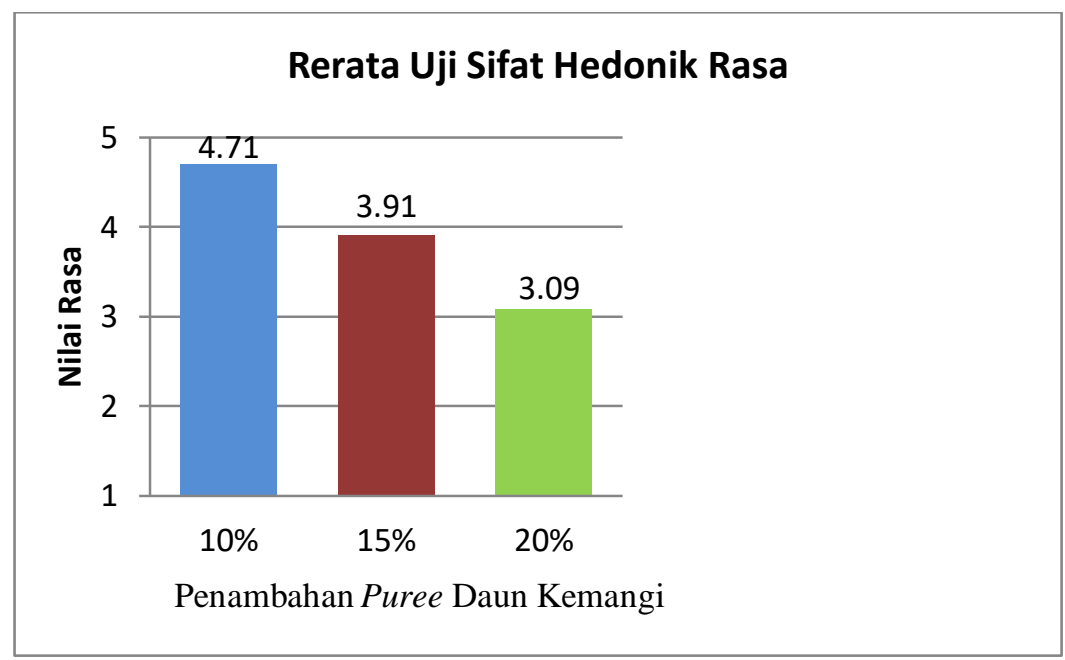

Picture 4.3: Average Taste Hedonic of Basil Leaves Biscuits

ANOVA analysis results showed that there were significant differences in the taste hedonic of basil leaves biscuits with the addition of basil leaves puree as much as $10 \%, 15 \%$, and $20 \%$. This is indicated by the significance value of $0,000<0.05$. Then continued with the Duncan's multiple range test (DMRT) to be used to determine the differences in each treatment.

It is known, based on Duncan's Multiple Range Test (DMRT) test results that there are significant differences in each treatment. Basil leaves biscuits with the formulation of adding basil leaves puree as much as $10 \%$, $15 \%$, and $20 \%$ each different. Based on research it is known that the more addition of basil leaves puree to the making of biscuits, the more panelists are unable to accept the taste of the biscuits.
Differences in the assessment of taste in each biscuit formula with the addition of basil leaves puree as much as $10 \%, 15 \%$, and $20 \%$ due to the increased amount of basil leaves puree so that the flavor of biscuits is somewhat spicy typical of basil leaves. Slightly spicy taste on basil leaves affects the level of favour on basil leaves biscuits. Spicy taste on basil leaves is caused by the essential oil content found in basil leaves (Gunardi, et al. 2010). According to Teuscher (2006) basil has a spice flavor, sometimes resembling pepper and sometimes refreshing. The difference in taste on basil leaves is due to several chemical compounds contained therein, especially methyl chavicol (orestragol), linalool, citral, methyl cinnamate, and euganol (Raghavan, 2000).

\section{Texture Hedonics}

Texture hedonic of basil leaves biscuits with the formulation of adding basil leaves puree as much as $10 \%, 15 \%$, and $20 \%$ can be seen in the Picture 4.4.

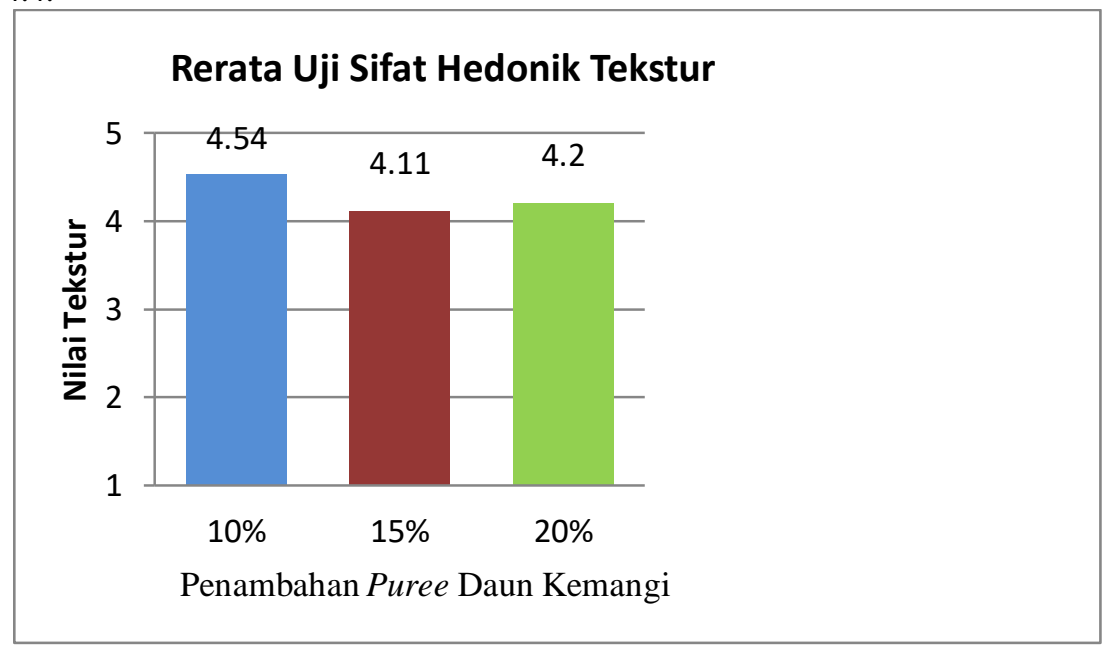


Picture 4.4: Average Texture Hedonic of Basil Leaves Biscuits

ANOVA analysis results showed that there were significant differences in the texture hedonic of basil leaves biscuits with the addition of basil leaves puree as much as $10 \%, 15 \%$, and $20 \%$. This is indicated by the significance value of $0,004<0.05$. Then continued with the Duncan's multiple range test (DMRT) to be used to determine the differences in each treatment.

It is known, based on the results of Duncan's Multiple Range Test (DMRT) that there is a significant difference in the level of texture preference for basil leaves with the addition of basil puree as much as $10 \%$ is significantly different from the formulation for adding basil leaves as much as $15 \%$, and $20 \%$. The preferred level of biscuit texture for the formulation of adding basil leaves puree by
$15 \%$ was not significantly different from the formulation for adding basil leaves puree by $20 \%$.

This is due to the addition of different basil leaves puree which affects the preference level of the settler for the texture of the basil leaves biscuits. Panelists tended to prefer biscuits with the addition of $10 \%$ of basil leaves puree using 10 grams of 100 grams of medium protein wheat flour because the texture of the biscuits with the formula was crisper. The lower the addition of basil leaves puree, the more crunchy the texture of the biscuits.

According Nurdjanah, et al (2011) states that the water content in biscuits is a characteristic that will affect consumer acceptance, especially in the texture or crispness level of biscuits. In the process of mixing ingredients, printing and baking also affect the texture of the biscuits (Wulandari \& Erma, 2010).

\section{Colour Hedonics}

Colour hedonic of basil leaves biscuits with the formulation of adding basil leaves puree as much as $10 \%, 15 \%$, and $20 \%$ can be seen in the Picture 4.5.

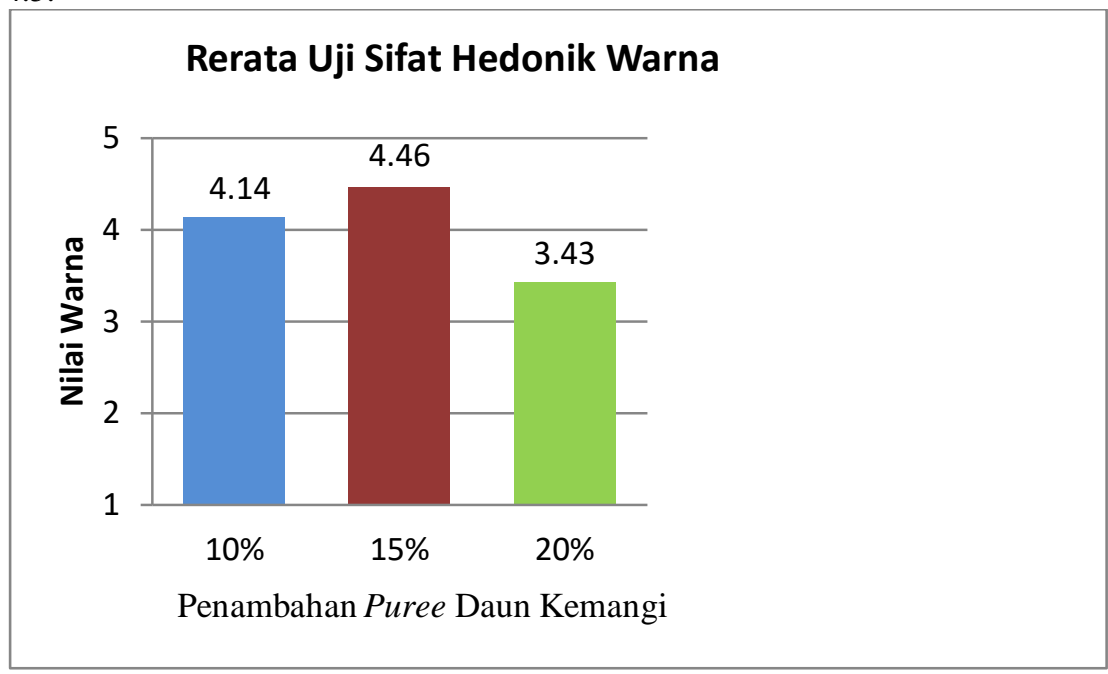

Picture 4.5: Average Colour Hedonic of Basil Leaves Biscuits

ANOVA analysis results showed that there were significant differences in the colour hedonic of basil leaves biscuits with the addition of basil leaves puree as much as $10 \%, 15 \%$, and $20 \%$. This is indicated by the significance value of $0,000<0.05$. Then continued with the Duncan's multiple range test (DMRT) to be used to determine the differences in each treatment.

It is known, based on the results of Duncan's Multiple Range Test (DMRT) that there is a significant difference in the degree of colour preference for basil biscuit leaves with a formulation of adding $10 \%$ of basil leaves puree is not significantly different from the formulation for adding basil leaves puree by $15 \%$. The favorite level of biscuit colour formulation with the addition of basil leaves puree by $20 \%$ is significantly different from the formulation for adding basil leaves puree by $10 \%$ and $15 \%$.

This is because the colour of biscuits adding $15 \%$ basil leaves is considered to have a bright green color, while biscuits with the addition of $10 \%$ basil leaves puree have a yellowish green color. Biscuits with the addition of $20 \%$ basil leaves puree have a color that is too strong or so the panelists don't like it much. This is suspected because the basil contains chlorophyll.

The colour of the basil leaves biscuits resulting from the formulation of the addition of basil leaves puree is greenish yellow to dark green. The more addition of basil color puree leaves to the biscuits will be more green, the more chlorophyll content in the biscuits.

According to Winarno, 2008, chlorophyll contained in chloroplasts. These cells will rupture due to grinding so that the pigment will come out and some will be damaged or oxidized due to contact with air. Foodstuffs undergoing processing or heating can be expected to experience significant changes in the color of foodstuffs (Muchtadi, 2010). 


\section{Flavour Hedonics}

Flavour hedonic of basil leaves biscuits with the formulation of adding basil leaves puree as much as $10 \%, 15 \%$, and $20 \%$ can be seen in the Picture 4.6.

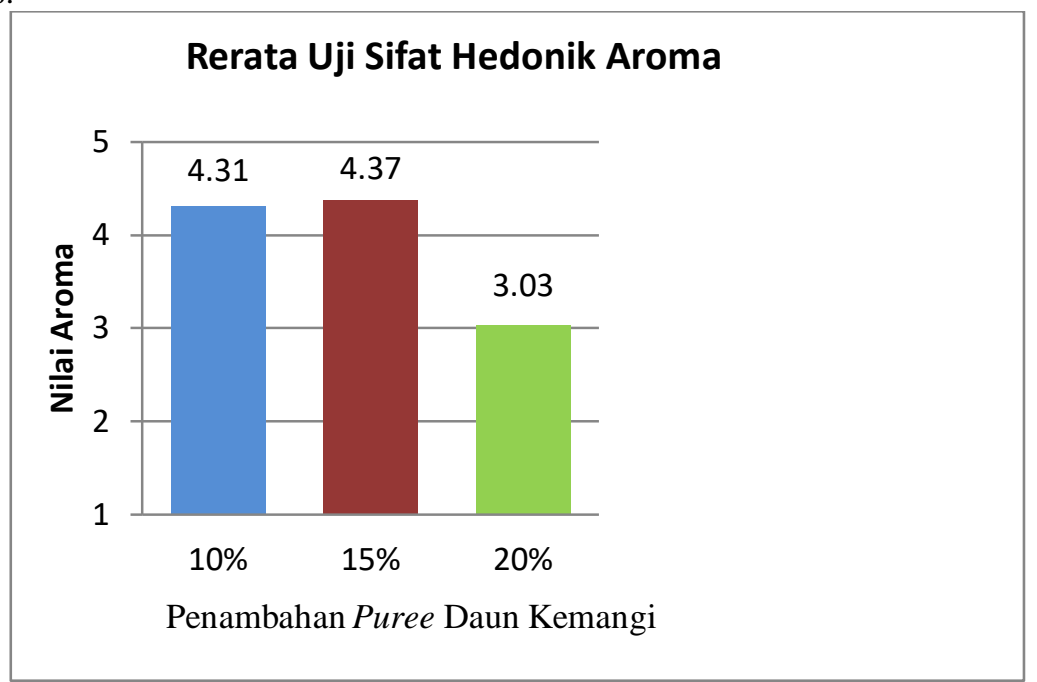

Picture 4.6: Average Flavour Hedonic of Basil Leaves Biscuits

ANOVA analysis results showed that there were significant differences in the colour hedonic of basil leaves biscuits with the addition of basil leaves puree as much as $10 \%, 15 \%$, and $20 \%$. This is indicated by the significance value of $0,000<0.05$. Then continued with the Duncan's multiple range test (DMRT) to be used to determine the differences in each treatment.

It is known, based on the results of the Duncan's Multiple Range Test (DMRT) that there is a significant difference in the preferred level of aroma of basil biscuit leaves with a formulation of adding $10 \%$ of basil leaves puree is not significantly different from the formulation of adding $15 \%$ of basil leaves puree. The favorite level of biscuit aroma formulation with the addition of basil leaves puree by $20 \%$ was significantly different from the formulation for adding basil leaves puree by $10 \%$ and $15 \%$.

It is known that the addition of basil leaves puree affects the level of panelists' preference for aroma in the basil leaves biscuits. The aroma of basil biscuits with the addition of $15 \%$ of basil leaves puree is most preferred compared to the formula for the addition of $10 \%$, and $20 \%$ for basil leaves. This is because biscuits with the addition of $10 \%$ basil leaves puree have a not-so-strong aroma typical of the main ingredient and biscuits with the addition of $20 \%$ basil leaves puree have a very strong basil leaves aroma so panelists don't like it.

The high level of aroma preference for basil leaves biscuits is caused by the addition of basil leaves puree which has a very distinctive aroma coming from the leaves which are very strong but soft with a touch of lime scent. Basil leaves have a distinctive, strong aroma with a hint of lime (Utami, et al. 2008). The unique aromatic odor of basil leaves also comes from the essential oil content which is concentrated in the leaves which is known to have the main active ingredient of eugenol as much as $71 \%$ which can also stimulate salivary production by neuronal means through the autonomic nervous system, both sympathetic and parasympathetic (Shinta, 2012) .

\section{REFERENCES}

[1] Aini, Nur. 2010. Komponen Fungsional dalam Buah dan Sayur. Majalah Bulanan Kulinologi Indonesia, hlm.43-44. Astawan, M \& Kasih, L.A. 2008. Khasiat Warna-warni Makanan. Jakarta:Gramedia Pustaka Utama.

[2] Chahyanto., Bibi, Ahmad., \& Roosita, Katrin. 2013. Kaitan Asupan Vitamin A dengan Produksi Air Susu Ibu (Asi) pada Ibu Nifas. Jurnal Gizi dan Pangan, (Online), 8 (2): 8388, diakses 28 Desember 2018.

[3] Erawati, Christina M. 2006. Kedelai Stabilitas $\beta$-karoten Selama Proses Produksi Tepung Ubi Jalar. Tesis tidak diterbitkan. Bogor: Pascasarjana Institut Pertanian Bogor.

[4] Gunardi \& D.P. Dewi. 2010. Pemisahan Minyak Atsiri Kemangi (Ocimum Basilicum Linn)secara Kromatografi Lapis Tipis dan Aktivitasnya terhadap Malssezia furfu In Vitro.Artikel Ilmiah. Median Medika Muda.

[5] Halwati, Saumi. 2015. Pengaruh Teknik Pengolahan Terhadap Kandungan B-Karoten Serta Penerimaan Ibu Hamil Dan Menyusui Terhadap Mi Kelor Instan. Skripsi tidak diterbitkan. FT UM.

[6] Kundre Rina, Pondaag Linnie. 2017. Hubungan Pemenuhan Kebutuhan Gizi Ibu dengan Kelancaran Air Susu Ibu (Asi) Pada 
Ibu Menyusui Di Puskesmas Bahu Kota Manad. e-journal Keperawatan (e-Kp) Volume 5 Nomor 1, Februari 2017.

[7] Lee, H. S. 2000. HPLC Analysis of phenolic compounds. Di dalam : Nollet, L. M. L. (Ed.). Food Analysis by HPLC, Second Edition, Revised and Expanded. Marcel Dekker, Inc., New York.

[8] Made Astawan. 2015. Kandungan Gizi Daun Kemangi. Institut Pertanian Bogor. Bogor

[9] Muchtadi Tien R. Fitriyono Ayustaningwarno. 2010. Teknologi Proses Pengolahan Pangan. Bandung: Alfabeta.

[10] Nurdjanah, S., Musita, N., Indrianti, D. 2011. Karakteristik Biskuit Coklat dari Campuran Tepung Pisang Batu (Musa balbisiana colla) dan Tepung Terigu pada Berbagai Tingkat Substitusi. Jurnal Teknologi dan Industri Hasil Pertanian 1(16), 51-62.

[11] Putra, A. 2013. Pembuatan white chocolate dengan variasi CBS (Cocoa Butter Subsitute) dan perbandingan gula dengan susu full cream. Skripsi tidak diterbitkan. Yogyakarta: Institut Pertanian Stiper Yogyakarta.

[12] Raghavan, Susheela. 2000. A Handbook of Spices, Seasonings, and Flavorings. Technomic Publishing Company, Inc. United States of America.

[13] Septika, Widyawati Nuri. 2018. Formulasi Cookies Berbahan Dasar Pangan Lokal Sebagai Alternatif Snack Bagi Ibu Hamil. Skripsi tidak diterbitkan. Bogor: Fakultas Ekologi Manusia IPB.

[14] Shinta. 2012. Potensi Minyak Atsiri Daun Nilam (Pogostemon cablin B.), Daun
Babadotan (Ageratum conyzoides L), Bunga Kenanga (Cananga odorata hook F \& Thoms) dan Daun Rosemary (Rosmarinus officinalis L) sebagai Repelan Terhadap Nyamuk Aedes aegypti L, Media Litbang Kesehatan. 22(2): 61-69.

[15] Syarief, Hidayat., Martua, Damanik R., Sinaga, Tiurma., \& Herta, Doloksaribu T. 2014. PemanfaatanDaun Bangun-Bangun dalam Pengembangan Produk Makanan Tambahan Fungsional untuk Ibu Menyusui. Jurnal Ilmu Pertanian Indonesia (JIPI), Vol. 19 (1): $\quad 38-42 . \quad$ Dari http:/oaji.net/articles/2015/21261434607752.pdf.

[16] Teuscher, Eberhard. 2006. Medicinal Spices: A Handbook of Culinary Herbs,Spices, Spice Mixtures and Their Essential Oils. Medpharm Scientific Publishers Stuttgart. Germany.

[17] Utami, Dr. Prapti (2008). Buku Pintar Tanaman Obat:431 Tanaman Penggempur Aneka Penyakit. Tangerang: AgroMedia Pustaka. ISBN 979 006-194-3.

[18] Winarno, F.G. 2004. Kimia Pangan dan Gizi. Jakarta: Gramedia Pustaka Utama.

[19] Winarno, F.G. 2008. Kimia Pangan dan Gizi: Edisi Terbaru. Jakarta. Gramedia Pustaka Utama.

[20] Wulandari, Mita, dan Handarsai, Erma. 2012. Pengaruh Penambahan Bekatul terhadap Kadar Protein dan Sifat Organoleptik Biskuit. Jurnal Pangan dan Gizi Vol 01 No. 02 Tahun 2010. Dari

https://media.neliti.com/media/publications/11 6310-ID-none.pdf 